\title{
Trajectory of Undergraduates' Ideological and Political Education Against the Background of Entrepreneurship and Chinese Dreams
}

\author{
Caiqin Liang \\ Sichuan Vocational \& Technical College, Sichuan, 629000, China
}

\begin{abstract}
Keywords: Entrepreneurship, Chinese Dream, Background, College Students, Ideological and Political Education, Work, Conduct, Trajectory, Analysis.
\end{abstract}

\begin{abstract}
Currently, education is faced with serious challenges and rare development opportunities. The education workers of ideological and political institutions in colleges and universities need to actively explore the new path of ideological and political education in the new situation. All of us have made great progress in all the undertakings of socialism with Chinese characteristics in our endeavor to realize the "Chinese dream". The ideological and political education of college students has not achieved its due effect, and there are some problems such as vague political thought, pluralistic values and deviation of moral evaluation.
\end{abstract}

\section{Introduction}

Colleges and universities as the important base of training builders and successors for the socialist cause and places, bear the talents cultivation, scientific research, social services, cultural heritage and other important tasks and mission, for identifying national prosperity and rejuvenation, the people's happiness Chinese dream plays a critical role. In order to cultivate more qualified and excellent talents, universities should attach great importance to ideological and political education work, based on the reality of domestic and international background and conditions, the innovation thought political governance concept, way and method of education, to explore good path up the ideological and political education, ideological and political education of college students and improve the needle to sex and effectiveness.

$\mathrm{Xi}$ "China dream" is the chairman of the communist party of China Eighteen big thought theory further embodiment represents a blueprint for comprehensive recovery of the Chinese nation, is a comprehensive summary of the construction of socialism with Chinese characteristics. The concept of "Chinese dream" makes college students more clearly about their own general goals, and initiatively combines their own values with the dream of a rejuvenated country. In the face of the current situation of college students' ideological and political education, to achieve the "China dream", then give the related contents into the ideological and political education, with the "China dream" in the spirit to lead the college students' thought, building socialism with Chinese characteristics of ideological and political education system.

\section{The Proposed Methodology}

Problems in College Ideological and Political Education. At present, due to many factors such as social and historical reasons, college students' awareness of politics is very vague and shows the phenomenon of chaos in political thinking. Some college students have a tendency of utilitarianism in their political conception, and they will join the party and serve as student council cadres as a means to enhance their employability. Considering problems simply from their own development, they have shortsighted eyes, impetuous emotions and pragmatism. Some college students appear desalination, confusion and lack of faith. Indifference to political life, insensitivity to political life, irrational political views, and unclear political positions.

In recent years, with the rapid development of social economy and culture, there has been an in-depth exchange between Oriental culture and Western culture. Different ideological cultures have had a certain impact on college students' ideological concepts, which has created a diversified value 
orientation for college students. The undergraduates' mainstream values have been weakened, and even the cognition of the meaning of life has also been changed, showing an individualistic tendency. With the development of market economy, the moral values of undergraduates are influenced by some negative thoughts in society, and there is a serious moral decline. Some college students take double or multiple standards to treat themselves and others in the process of practice, and only pay attention to the gain of interests and rights. Some college students treat socialism as cynical and turn away from traditional morality. Still others are rude and have poor ideas.

As a special social group, undergraduates face more and more complex problems, their psychological endurance is getting worse and worse, some extremities are prone to occur, which has a great impact on their physical and mental health. Part of the college students in the face of complex relationships, interpersonal relationships, affection, employment options and other complex contradictions, there are many psychological problems at stake. Part of college students face the relative closed environment of college students, loneliness, indifference, depressed social environment and other objective factors, there uneasy, dissatisfied negative psychology.

Relationship between "China Dream" and College Students' Ideological and Political Education. The "Chinese dream" includes the harmonious China, the democratic China, the rich China, the Chinese civilization, the beautiful China and the humanity China, etc., is the people's yearning for the future development of China. The "Chinese dream" is also the dream of every college student, every Chinese dream. The ideal belief of every college student should be to unite all the forces that can be united and unite into a spirit of perseverance, so that the "Chinese dream" will eventually come true. Whether in the past "may fourth" movement, or in the new era of socialism with Chinese characteristics, college students have played a very important role. With the rapid development of science and technology, college students are the main force in the mastery of high and new technology, the most precious resource of human resources, and the source of the rejuvenation of the motherland. College students have become the driving force for realizing the "Chinese dream", and realizing the "dream of China" is also the great historical mission of college students.

On April 8, 2013, yun-shan liu in deepening the "Chinese dream" propaganda education symposium pointed out: "to the" China dream "in the promotion of the education is incorporated in the education teaching of schools of various levels, into the minors' ideological and ethical construction and the ideological and political education in university, merge in the construction of campus culture". The basic condition of the realization of the "Chinese dream" is education, which can only achieve the qualitative change of the "Chinese dream". The "Chinese dream" contains rich connotations, leading the spirit of The Times, and the university's ideological and political education should take this as an opportunity to strengthen the "Chinese dream" propaganda education. The goal of the "Chinese dream" is combined with the goal of education of the university students' ideological and political science, and the path of innovative college students' ideological and political education.

Ways of College Students' Ideological and Political Education. Teachers should integrate the relevant content of "China Dream" into education and teaching. On the one hand, they should focus on the concept of innovative teaching. Starting from the internal needs of college students, thinking reality, accepting the psychology and accepting the law, we carry out the theme education of "China Dream", and determine the teaching contents pertinently according to the different internal needs of students at different levels, ideas and attitudes, as well as different interests and hobbies to make targeted teaching adjustments in order to achieve specific teaching goals. The teaching concept of "China Dream" should motivate students to think positively, study harder on science and culture, believe more in the scientific nature of Marxism and recognize the core values of socialism. On the other hand, to update the teaching content as the concept of textbook content, principles, methodology should continue to update, pay attention to practicality. The teaching content should not only combine teaching material closely, but also walk into the real life of college students, broaden the theoretical knowledge of teaching materials with "Chinese Dream" and solve the new problems and new situations encountered by students. Students concerned about some social hot spots, doubts, with the 
latest "China Dream" theory to give timely diagnosis, analysis of its advantages and disadvantages, so that students agree with the "China Dream" led by the theme of education.

Campus culture has the function of promoting the development of higher education. At the same time, as a primary carrier of ideological and political education, it plays a guiding role in promoting the positive values of college students. To carry out the "China Dream" theme activities, first of all, to strengthen the layout of the campus environment, planning and design. Campus environment should be based on student teaching, student sports, student life and other functions to locate the distinction, to carry out campus activities should try to avoid affecting the teaching activities. School bulletin boards designed to be reasonable, posters should be ordered, cultural landscape should be appropriate, and so on. These measures can enhance the campus culture, inspire students love school enthusiasm. Second, make active use of new media technologies. New media technology can effectively promote ideological and political education, to achieve immediate results. In the campus BBS forum, Weibo, WeChat, QQ group, campus TV and the other new media technology platform implanted "China Dream" theme education content. Finally, organize a variety of campus activities to enrich students' extracurricular life. The school can carefully organize new forms of campus cultural activities, especially the use of major holidays to carry out a number of activities based on the theme of "Chinese Dream," such as the "China Dream" as the theme of the evening party, "China Dream" as the theme of the speech Competitions, etc., and integrate relevant contents of ideological and political education into activities so as to make students feel and enlighten in subtle influences. In short, the construction of campus culture and the launching of the "China Dream" theme activity have a very favorable effect on the ideological and political education for college students and can guide ideological and political education toward a more attractive and targeted direction.

The combination of theoretical education and practical education is the key to ideological and political education of college students, which is of great significance in college students' ideological and political education. College students should actively participate in social practice, deepen their understanding of socialist construction and reform, and deepen their understanding of the party's line and line so as to strengthen their own ideals and beliefs. In the great journey of "China's dream," patriotism means making our country prosperous and prosperous, and contributing its own talents and strength to realizing the great rejuvenation of the Chinese nation. Colleges and universities can organize students to the revolutionary memorial hall, the red base to visit and study, patriotism education, so that students understand the Chinese revolution, understand the course of development of the Chinese nation, understand the importance of patriotism. Colleges and universities can also organize students to welfare homes, homes for the elderly, volunteer work, poverty alleviation and poverty alleviation, education of love and compassion, understanding of the reality of our country and understanding of the fine traditions of the Chinese nation so that they may realize the great significance of realizing the "Chinese Dream." Colleges and universities can also strengthen the professional practice base, venture capital base, outdoor expansion base construction, with "China Dream" theory to guide college students in production practice.

Public entrepreneurship and ideological and political education. The "Chinese Dream" is fully integrated into the ideological and political education of college students and a long-term mechanism must be established to ensure that the "Chinese Dream" has become the common pursuit of value for teachers and students in colleges and universities. First, establish a leadership pooling mechanism. The leaders of all colleges and universities should pay attention to the launching of the educational activities on the theme of "China Dream", attach importance to the excavation of the connotation of "China's dream", incorporate the thinking on "China's dreams" into the agenda of major schools and establish a working mechanism of leading and coordinating. Second, establish a funding guarantee system. Adequate funding is the key to ensure the integration of "China's Dream" with ideological and political education in colleges and universities. If funding is insufficient, ideological and political education can hardly be truly implemented. Again, establish evaluation and evaluation mechanism to establish an effective evaluation system of the "China Dream" publicity and education, the effectiveness of publicity and education into performance evaluation, and constantly inject new 
elements into the propaganda and education. Finally, establish a monitoring and inspection mechanism. The major universities and colleges may set up the supervision and inspection team to supervise and inspect the implementation of the "China Dream" in ideological and political education so as to ensure that "the Chinese dream" can be implemented in ideological and political education.

Opportunities Faced by College Students' Ideological and Political Education. At present, with the transformation of our economic system and the improvement of living standards, people's thinking and thinking have gradually become diversified. This poses a severe challenge to the cultivation of the mainstream values of college students. At present, the socialist market economy in our country is gradually deepening. Interests of all classes and strata are constantly being adjusted. People's thinking and thinking modes are gradually diversified. The formation of university students' world outlook, outlook on life and values is influenced by the social, family, Schools and other atmosphere, it is not easy for them to consciously accept the mainstream values that accord with the basic principles of Marxism.

With the rapid development of multimedia and internet technology, the new campus media with campus internet and mobile phone information platform as the main body has provided a new carrier for the ideological and political education in colleges and universities, which has ushered in a rare opportunity for ideological and political education in colleges and universities. The rapid development of network and information technology, the rapid, non-barrier, extensiveness and virtuality of campus new media based on campus internet and mobile phone information platform have brought severe challenges to ideological and political education in colleges and universities, Ideological and political work has brought a rare opportunity for development. Through the website of the campus, WeChat WeChat group, electronic display, etc., colleges propagandize the party's line, principles and policies to educate students on their ideological and moral education, promote the typical characters and deeds around them, and criticize the bad behaviors and behaviors among students. By giving full play to the new media in a timely, rapid, strong affinity and acceptable character, it has innovated the carriers and means of ideological and political education and laid a solid foundation for the actual effectiveness of ideological and political education.

\section{Conclusion}

The work of ideological and political education of college students is not done in a single step. Ideological and political education workers in colleges and universities should be in the process of realizing "China's dream." According to the actual situation of undergraduates, take patience to take a different path to clear education, to guide undergraduates to deepen their understanding of "China's dream" and promote the organic integration of "China's dream" and college students' ideological and political education. The path of undergraduates' ideological and political education from the perspective of Chinese dream is as follows: through the means of family education, the demonstration and vigilance of social education, etc., all these can promote the ideological and political education workers in colleges and universities to think in order to better carry out college students Ideological and political education.

\section{References}

[1]. Hardy, C. and Maguire, S., 2017. Institutional Entrepreneurship and Change in Fields1. The SAGE Handbook of Organizational Institutionalism, p.261.

[2]. Arpiainen, R.L. and Tynjälä, P., 2017. Introducing Team Learning in a Developing Economy: Students' Experiences of Experiential Entrepreneurship Education in Namibia. Journal of enterprising culture, 25(02), pp.179-210. 
[3]. Wang, Y., Li, J. and Wang, H.H., 2017. Cluster and cloud computing framework for scientific metrology in flow control. Cluster Computing, pp.1-10.

[4]. González, M.F., Husted, B.W. and Aigner, D.J., 2017. Opportunity discovery and creation in social entrepreneurship: An exploratory study in Mexico. Journal of Business Research, 81, pp.212-220. 